\title{
Availability of tree cavities in a sal forest of Nepal
}

\author{
Prabin Bhusal ${ }^{(1)}$, \\ Dorota Czeszczewik ${ }^{(2)}$, \\ Wiesław Walankiewicz ${ }^{(2)}$, \\ Marcin Churski ${ }^{(3)}$, \\ Rishi Baral ${ }^{(4)}$, \\ Babu Ram Lamichhane (5), \\ Grzegorz Mikusiński ${ }^{(6-7)}$
}

\begin{abstract}
Tree cavities are important structural elements of forest ecosystem that host numerous birds, mammals and other cavity-dependent organisms. Pattern of cavity distribution in temperate and boreal forests are relatively well studied, yet little is known about cavities in tropical and subtropical forests. We compared cavity availability in relation to tree condition (living tree and snag), tree species and DBH class between two different sites in a subtropical deciduous sal forest in Nepal: the Chitwan National Park Forest (the park site) and the Khorsor Buffer Zone Forest (the buffer site). Surveys for tree cavities were conducted in 2013 on 50 circular sample plots of size 0.1 ha. We recorded 40 cavity trees in the park site and 31 cavity trees in the buffer site. Density of cavities was on average $22.4 \mathrm{ha}^{-1}$ in the park site and $19.2 \mathrm{ha}^{-1}$ in the buffer site. Cavities occurred mostly in living trees $(85.9 \%$ cavity trees) and were formed mostly by damage and decay (natural cavities: $74 \%$ ) or by woodpecker activity (excavated cavities: $26 \%$ ). Most were observed on three tree species: Shorea robusta, Dillenia pentagyna and Syzygium operculatum, with a mean diameter of $43 \mathrm{~cm}$ (range: 12-111 cm). S. operculatum, Myrsine semiserrata and Semecarpus anacardium were overrepresented among tree species with cavities. In snags, $25.0 \%$ of all cavities were found in the park site and $8.3 \%$ in the buffer site, while snags represented $4.2 \%$ and $2.2 \%$ of all trees in the two sites, respectively. Statistical anaysis indicated that tree species, tree condition and particularly diameter (DBH) were important variables for the prediction of cavity presence. We recommend cavity-bearing tree species to be better protected by forest management in order to help maintain the community of cavity dwellers.
\end{abstract}

Keywords: Chitwan National Park, Natural Cavities, Excavated Cavities, Subtropical Forest, Tree Holes

(Von Haartman 1957, Newton 1994, Newton 1998, Cornelius et al. 2008). Such a limitation seems apparent in cavity-poor, managed forests, where trees are usually harvested before reaching a suitable size for cavity formation. Moreover, foresters actively remove the remaining old or dead trees (potentially cavity trees). The negative effect of such management is additionally reflected on the populations of woodpeckers, which are natural creators of ca-

(1) Tribhuvan University, Institute of Forestry, Pokhara Campus (Nepal); (2) Siedlce University, Faculty of Natural Science, Department of Zoology, Prusa 12, 08110 Siedlce (Poland); (3) Mammal Research Institute, Polish Academy of Sciences, Waszkiewicza 1, 17-230 Białowieża (Poland); (4) Tribhuvan University, Department of Zoology, Kathmandu (Nepal); (5) National Trust for Nature Conservation, Biodiversity Conservation Center, Ratnanagar -15, Sauraha, Chitwan (Nepal); (6) Swedish University of Agricultural Sciences, Department of Ecology, Grimsö Wildlife Research Station, SE-73091 Riddarhyttan (Sweden); (7) Swedish University of Agricultural Sciences, School for Forest Management, P.O. Box 43, SE-73921 Skinnskatteberg (Sweden)

@ Grzegorz Mikusiński (grzegorz.mikusinski@slu.se)

Received: Nov 05, 2014 - Accepted: Jul 08, 2015

Citation: Bhusal P, Czeszczewik D, Walankiewicz W, Churski M, Baral R, Lamichhane BR, Mikusiński G (2015). Availability of tree cavities in a sal forest of Nepal. iForest 9: 217-225. doi: 10.3832/ifor1493-008 [online 2015-10-16]

vities and are often dependent on old and dead trees (Mikusiński 2006). Such practices may lead to a general decline of forest biodiversity and is a major key issue in the forestry-conservation controversy (Poulsen 2002, Wesołowski 2005). However, in natural or semi-natural old growth forests it has demonstrated that a surplus of tree cavities exist and secondary cavity nesters are not usually limited by shortage of cavities (Edington \& Edington 1972, Waters et al. 1990, Walankiewicz 1991, Carlson et al. 1998, Bai et al. 2003). The age, species and size of trees have a primary role in defining the abundance and distribution of tree cavities (Wesołowski 2011, 2012, Hussain et al. 2013).

Cavities are predominantly found in old living or dead trees, however, bird species often occupy cavities located in middle-age living trees of medium size (Wesołowski 1996, Czeszczewik \& Walankiewicz 2003, Aitken \& Martin 2004, Walankiewicz et al. 2007). Patterns of cavity creation, life-span, and their use are obviously dependent on forest ecology and dynamics, and therefore differ between tropical and temperate regions.

It has been demonstrated that woodpeckers play a keystone role in some forests by providing cavities for other cavity-nesting species (Mikusiński 2006, Cockle et al. 
2011). Many woodpecker species nest in trunks, limbs or branches of dead trees (Bull et al. 1986, Angelstam \& Mikusiński 1994, Wesołowski 2011). However, the proportion of woodpecker-made (excavated) and non-excavated cavities may largely differ among different forest types (e.g., coniferous vs. deciduous, managed vs. nonmanaged), as well as the longevity of cavities and their attractiveness for different bird species (Wesołowski 2011, 2012). Moreover, the presence of cavities may differ at the individual tree level, since the specific history of each tree affects its suitability either for excavation by woodpeckers or developing natural cavities. All the above factors affect the availability of cavities and their ecological significance in the forests. It is therefore necessary to better understand how different forest management strategies affect the availability of cavities in different forest types, and their importance for the community of cavity-dependent organisms.

Although tree cavities are critical component of forest ecosystems worldwide, they have been mostly investigated in Europe and North America (Carlson et al. 1998, Aitken \& Martin 2004, Cockle et al. 2011, Remm \& Lõhmus 2011, Wesołowski 2012), while little is known about their characteristics and occupancy rate in Asia (Bai et al. 2003, Hussain et al. 2013), where forests often harbor a very diverse assemblages of woodpeckers (Lammertink 2004, Mikusiński 2006, Kumar et al. 2011) and likely a different community of cavity dependent organisms. As in other parts of the world, the maintenance of biological diversity is a major objective of the Nepal's protected areas, including the renowned Chitwan National Park located in the subtropical lowland region. Biodiversity conservation strategies aim to secure the presence of tree cavities (Cooke \& Hannon 2011) and maintain the complete guild of cavity nesters and other obligate users. Unfortunately, little is known about the availability, distribution and use of cavity trees in subtropical forests of Asian subcontinent.

In this study we examined the density and origin of tree cavities in the sal forests (i.e., broadly distributed forest type dominated by the sal tree - Shorea robusta) of the Chitwan National Park and its buffer zone. The ultimate goal was to describe tree cavities in terms of tree species, characteristics and conditions, in order to better understand the importance of primary cavity-nesters (excavators) as cavity creators. We compared two sites with different management regimes to assess the potential effect of different levels of human impact on the availability of cavity resources.

\section{Material and methods}

\section{Study area}

The study was conducted in the subtropical lowlands of the inner Terai region, namely in the Chitwan National Park (CNP), and in the adjoining buffer zone forest at Khorsor, in a valley between Siwalik and Mahabharat Mountain ranges, south-central Nepal (Fig. 1). The altitude in this area ranges from 110 to $850 \mathrm{~m}$ a.s.l. The region has a subtropical climate with a dry season (October-May) and a rainy monsoon period (June-September). The Chitwan National Park ( $27^{\circ} 34^{\prime}-27^{\circ} 68^{\prime} \mathrm{N}, 83^{\circ} 87^{\prime}-84^{\circ} 74^{\prime} \mathrm{E}$ ) covers $932 \mathrm{~km}^{2}$. For centuries, the Chitwan area has been used for royal hunting and managed in order to enhance the game through, e.g., low intensity fires to increase the annual production of grass (Nepal \& Weber 1995). Due to the high malaria risk until 1950s, only a few native malaria-resistant tribes (e.g., Tharu) were living in Chitwan based on non-intensive utilization of forests and grasslands supported by shifting cultivation (Müller-Böcker 1991). However, the eradication of malaria resulted in a massive population migrations and a large-scale forest clearing aimed at human settlements and crop cultivation (Nepal \&

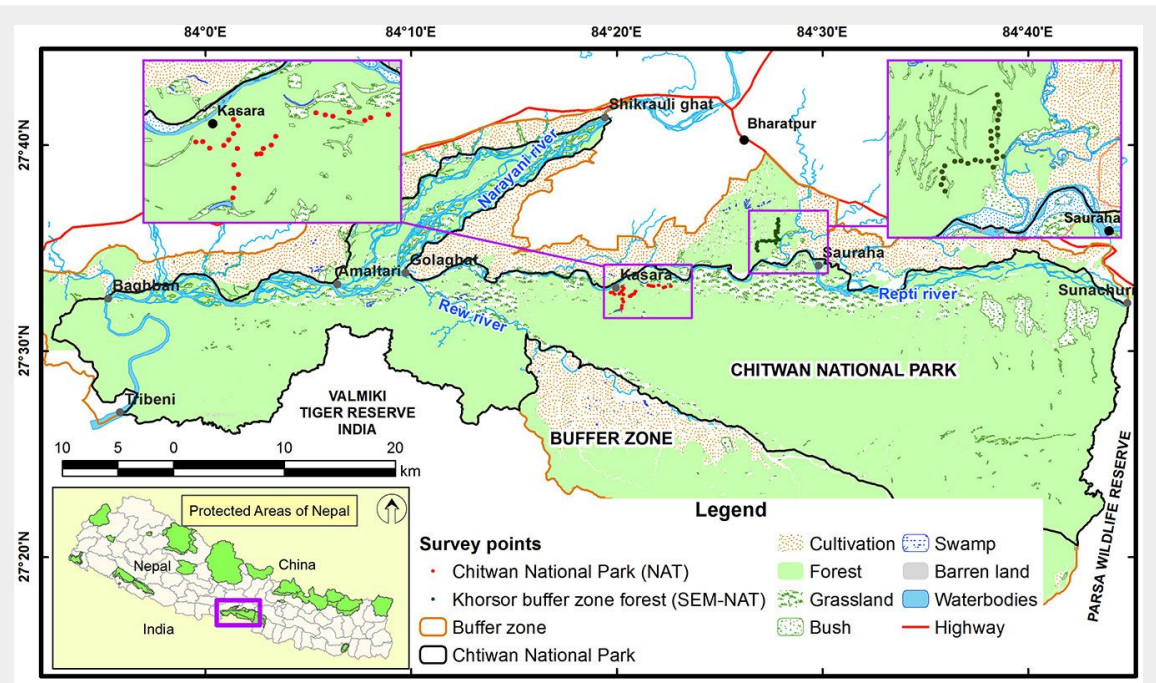

Fig. 1 - Location of the study area.

Weber 1995). The relatively unaffected part of the Chitwan area was declared as the first national park in Nepal in 1973. UNESCO declared CNP a World Heritage Site in 1984 (DNPWC 2011). The CNP is one of the best habitats for the Bengal tiger (Panthera tigris) in the world. This area is also renowned for its successful protection of the one-horned rhinoceros (Rhinoceros unicornis) and the gharial crocodile (Gavialis gangeticus), and is considered to have the highest population density of sloth bears (Melursus ursinus). A total of 68 species of mammals, 544 species of birds (including 22 globally threatened species), 56 species of herpetofauna and 126 species of fish have been recorded there. Several dozens of Chitwan's bird species like woodpeckers (Picidae), parakeets (Psittacula spp.), barbets (Megalaima spp.), hornbills (Bucerotidae), as well as some small and middle-size arboreal mammals and reptiles are all dependent on the presence of cavity trees. Seventy percent of the CNP vegetation cover is dominated by sal trees, in admixture with other tree species like Terminalia alata, Dillenia pentagyna, Syzygium operculatum and a number of other far less abundant tree species. Other major forest types at the CNP are riverine forests in floodplains or stands dominated by chir pine ( $\mathrm{Pi}$ nus roxburghii) located at higher elevations.

The sal forests covering substantial part of the CNP are regularly burned in early spring with low intensity fires, mostly burning the dry litter. Removal of dead wood is illegal though occurring (Straede \& Treue 2006). In 1996, an additional area of 750 $\mathrm{km}^{2}$ surrounding the Chitwan National Park (Fig. 1) was declared as "buffer zone". This consists of forests and other land-use types including cultivated lands (DNPWC 2011). The buffer zone forest at Khorsor is adjoined to the Chitrasen and Bagmara community, and delimits the southern border of the CNP. Khorsor forest serves as major source of firewood and sometimes (illegally) timber for local people. In addition, the area has been heavily used for grazing by livestock. Prescribed burning and dead wood removal are other major anthropogenic activities largely affecting the forest ecosystem. In summary, the buffer zone has generally the same forest and vegetation types as the area falling within the national park, but human impact is more intense.

\section{Sampling design}

Fieldwork was done during the dry season in March 2013. The study area included two sites with different forest conditions: (1) a site within the CNP, with relatively low human pressure (the park site); and (2) a managed forest corridor of buffer zone at Khorsor (the buffer site), where human pressure was higher (Fig. 1). The park site sample plots were located in central lowland part of the CNP $\left(27^{\circ} 35^{\prime}-27^{\circ} 36^{\prime} \mathrm{N}, 84^{\circ}\right.$ $19^{\prime}-84^{\circ} 22^{\prime} \mathrm{E} ; 135-182 \mathrm{~m}$ a.s.l.), while the 
buffer site sample plots were located in northern part of the buffer zone $\left(27^{\circ} 34^{\prime}\right.$ $27^{\circ} 36^{\prime} \mathrm{N}, 84^{\circ} 26^{\prime}-84^{\circ} 27^{\prime} \mathrm{E} ; 163-189 \mathrm{~m}$ a.s.l.). In each studied site, 25 circular sample plots of $17.8 \mathrm{~m}$ radius ( $0.1 \mathrm{ha}$ ) were established at least $250 \mathrm{~m}$ apart along a transect located on available forest roads or trails. Forests of Chitwan are interspersed by grasslands, thus the first point of each transect was located at least $150 \mathrm{~m}$ apart from the forest edge. Each plot center was placed at least $50 \mathrm{~m}$ within the forest in orthogonal direction from the main road, alternatively on the left or right side. Central points of each plots were set in the field using a Garmin GPS $76 \mathrm{CSx}^{\circledast}$ device (Garmin International Inc., Olathe, Kansas, USA). Next point on the transect was located by walking 250 meters along the main road and then moving 50 meters into the forest. When glades or meadows were encountered at the sampling point, we moved another 250 meters on transect to the next turn-point into the forest interior. The same applied for spots that were considered too dangerous, i.e., dense thickets with potentially hidden dangerous animals (tigers, rhinos, sloth bears, wild elephants). Additionally, at least two people equipped with bamboo sticks watched continuously for dangerous animals during data collection.

For all trees within each sample plots, the species, the diameter at breast height $(\mathrm{DBH})$ and the overall condition (live or dead) were recorded. Only trees with DBH $\geq 10 \mathrm{~cm}$ were recorded. Each tree was carefully inspected by at least two persons with binoculars. Detected cavities were checked using a ladder or/and a telescopic pole (up to $13 \mathrm{~m}$ long) with a low light diode and a webcam connected to a laptop. Using this device and a ladder we could investigate cavities up to $22 \mathrm{~m}$. Therefore, the number of tree cavities should be considered as the minimum number of cavities present on the plots, as some trees with cavities were out of reach. We defined a cavity as a hole in the tree with a minimum entrance diameter of $2 \mathrm{~cm}$, with the interior and bottom sufficient for small birds to nest in (a minimum bottom diameter of $5 \mathrm{~cm}$ ). Very large cavities (entrance diameters $>15 \mathrm{~cm}$ or depth $>70 \mathrm{~cm}$ ) were excluded from the analysis, since the study was focused on small and middle-size cavity-dependent birds.

Regarding the origin, cavities were divided into two categories: (i) non-excavated (natural cavities); (ii) excavated by woodpeckers (woodpecker-made cavities).

\section{Data analysis}

All sampled trees were divided into eight DBH classes: (I) 10-19 cm; (II) 20-29 cm; (III) 30-39 cm; (IV) $40-49 \mathrm{~cm}$; (V) 50-59 cm; (VI) $60-69 \mathrm{~cm}$; (VII) $70-79 \mathrm{~cm}$; (VIII) $80+\mathrm{cm}$. Six continuous density variables were analyzed: (a) of cavity trees; (b) all cavities; (c) natural cavities; (d) woodpecker-made cavities; (e) live trees; and (f) dead trees.
Tab. 1 - A comparison of the stand characteristics between Chitwan National Park (the park site) and Khorsor buffer zone forest (the buffer site).

\begin{tabular}{|c|c|c|c|c|c|c|}
\hline \multirow[t]{2}{*}{ Variables } & \multicolumn{2}{|l|}{$\begin{array}{l}\text { Park site } \\
(\mathrm{N}=25)\end{array}$} & \multicolumn{2}{|l|}{$\begin{array}{l}\text { Buffer site } \\
(N=25)\end{array}$} & \multicolumn{2}{|c|}{$\begin{array}{l}\text { Mann-Whitney } \\
\text { test }\end{array}$} \\
\hline & Mean \pm SE & Range & Mean \pm SE & Range & $\mathbf{U}$ & $\mathbf{P}$ \\
\hline Live trees $\mathrm{ha}^{-1}$ & $228.0 \pm 14.15$ & $40-330$ & $228.4 \pm 19.81$ & $40-470$ & 299.5 & 0.808 \\
\hline Snags ha ${ }^{-1}$ & $10.0 \pm 2.30$ & $0-50$ & $5.2 \pm 2.24$ & $0-50$ & 206.5 & 0.041 \\
\hline Cavity trees ha $^{-1}$ & $16.0 \pm 2.44$ & $0-40$ & $12.4 \pm 1.66$ & $0-30$ & 267.5 & 0.388 \\
\hline Cavities (all) ha ${ }^{-1}$ & $22.4 \pm 4.04$ & $0-50$ & $19.2 \pm 3.31$ & $0-60$ & 274.0 & 0.461 \\
\hline Natural cavities ha ${ }^{-1}$ & $16.0 \pm 2.82$ & $0-40$ & $14.8 \pm 3.0$ & $0-50$ & 291.5 & 0.691 \\
\hline Excavated cavities ha ${ }^{-1}$ & $6.4 \pm 1.72$ & $0-30$ & $4.4 \pm 1.30$ & $0-20$ & 279.5 & 0.528 \\
\hline
\end{tabular}

First, differences in the above-mentioned variables between the two study sites were examined by applying the MannWhitney's and the Chi-square tests, using the software package STATISTICA ${ }^{\circledast}$ version 10.0 (StatSoft 2011). To evaluate the selectivity of cavity trees in relation to the available tree species and DBH classes, we calculated the Ivlev's electivity index (Jacobs 1974 - eqn. 1):

$$
E_{i}=\frac{r_{i}-p_{i}}{r_{i}+p_{i}}
$$

where the electivity $(E)$ is a function of the availability of a tree species (or DBH class) in the study plots $(p)$, and their relative cavity presence $(r)$. Available trees and cavity trees were expressed as mean percentage values. $E$ values range from -1.0 to +1.0 with positive values indicating overrepresented and negative values indicating underrepresented trees, and zero for no selection.

Second, to analyze the relationship between several predictor variables (tree characteristics) and the binary response variable "incidence of tree cavities" $(0,1)$, generalized linear models (GLMs) with binomial error distribution were computed using the statistical software $R$ version 3.0.2 ( $R$ Development Core Team 2013). Explanatory variables used in the model were: (1) the tree species (nine species including those very rare that were combined into one category); (2) the site (park site/buffer site); (3) the tree condition (dead or alive); (4) DBH (covariate). The initial model included the main effects (Tree species, Site, Tree condition and $\mathrm{DBH}$ ) and three 2-way interactions between the categorical variables and DBH. Only those interactions which were biologically most meaningful for our study were included. For each model, we calculated the Akaike's information criterion (AIC) and the Akaike weight ( $w$ - Burnham \& Anderson 2002). The best model (minimal adequate model) was identified by a stepwise deletion procedure based on AIC (Hosmer et al. 1989). We calculated the area under the curve (AUC) as a measure of binary classifier performance (proportion of true positives and false positives). An AUC value of 1 indicates perfect classifier performance (all cases correctly classified) and a value of 0.5 indicates a classifier performance similar to randomness. A 0.05 level of significance was used.

\section{Results}

\section{Tree species composition and size distribution}

In total, we recorded 1041 live trees and 38 snags. The density of live trees was very similar at both sites (228.0 $\mathrm{ha}^{-1}$ in the park site, $\mathrm{N}=25$; and 228.4 ha $^{-1}$ in the buffer site,
Tab. 2 - Density of tree species (trees ha ${ }^{-1}$ ) in the park site and the buffer site.

\begin{tabular}{lcccc}
\hline \multirow{2}{*}{ Tree species } & \multicolumn{2}{l}{ Park site $\mathbf{( N}=\mathbf{2 5})$} & \multicolumn{2}{c}{ Buffer site $\mathbf{( N}=\mathbf{2 5})$} \\
\cline { 2 - 5 } & Mean \pm SE & Percentage & Mean \pm SE & Percentage \\
\hline Shorea robusta & $112.8 \pm 12.27$ & 49.5 & $104.4 \pm 13.68$ & 45.7 \\
Dillenia pentagyna & $44.4 \pm 7.03$ & 19.5 & $49.2 \pm 11.42$ & 21.5 \\
Syzygium operculatum & $43.6 \pm 7.85$ & 19.1 & $10.0 \pm 3.78$ & 4.4 \\
Myrsine semiserrata & $6.8 \pm 3.35$ & 3.0 & $1.6 \pm 1.24$ & 0.7 \\
Toona ciliata & $4.8 \pm 2.71$ & 2.1 & 0 & 0 \\
Semecarpus anacardium & $4.4 \pm 2.45$ & 1.9 & $1.2 \pm 0.87$ & 0.5 \\
Trewia nudiflora & $4.0 \pm 2.16$ & 1.8 & $0.4 \pm 0.40$ & 0.2 \\
Litsea monopetala & $2.4 \pm 1.44$ & 1.1 & $4.0 \pm 1.6$ & 1.8 \\
Tamarindus indica & $2.0 \pm 1.63$ & 0.9 & 0 & 0 \\
Syzygium cumini & $0.8 \pm 0.55$ & 0.4 & $0.4 \pm 0.40$ & 0.2 \\
Emblica officinalis & $0.8 \pm 0.80$ & 0.2 & 0 & 0 \\
Terminalia belerica & $0.4 \pm 0.40$ & 0.2 & $2.4 \pm 1.44$ & 1.1 \\
Terminalia chebula & $0.4 \pm 0.40$ & 0.2 & 0 & 0 \\
Xeromphis uliginosa & $0.4 \pm 0.40$ & 0.2 & 0 & 0 \\
Terminalia alata & 0 & 0 & $51.6 \pm 9.18$ & 22.6 \\
Terminalia termentosa & 0 & 0 & $2.4 \pm 1.32$ & 1.1 \\
Mallotus philippensis & 0 & 0 & $0.4 \pm 0.40$ & 0.2 \\
Spondias pinnata & 0 & 0 & $0.4 \pm 0.40$ & 0.2 \\
Total & 228.0 & 100 & 228.4 & 100 \\
\hline
\end{tabular}


Fig. 2 - Distribution of all live trees according their DBH classes in the sal forest. Colors represent the two study sites: green the park site (lower human pressure, $\mathrm{N}=25$ ) and yellow - the buffer site (higher human pressure, $\mathrm{N}=25$ ). Mean and SE are shown.

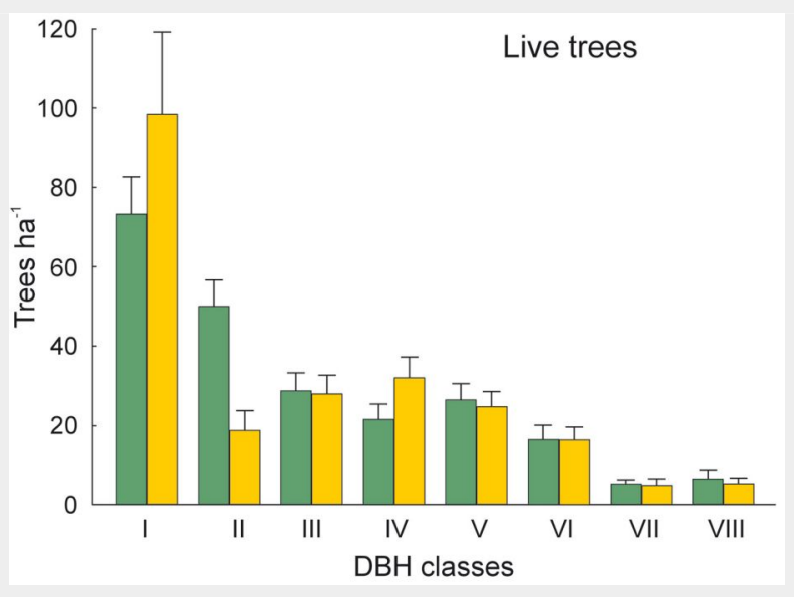

Fig. 3 - Distribution of Shorea robusta according its DBH classes in the sal forest. Colors represent the two study sites: green - the park site (low human pressure, $\mathrm{N}=25$ ) and yellow - the buffer site (higher human pressure, $\mathrm{N}=25$ ). Mean and SE are shown.

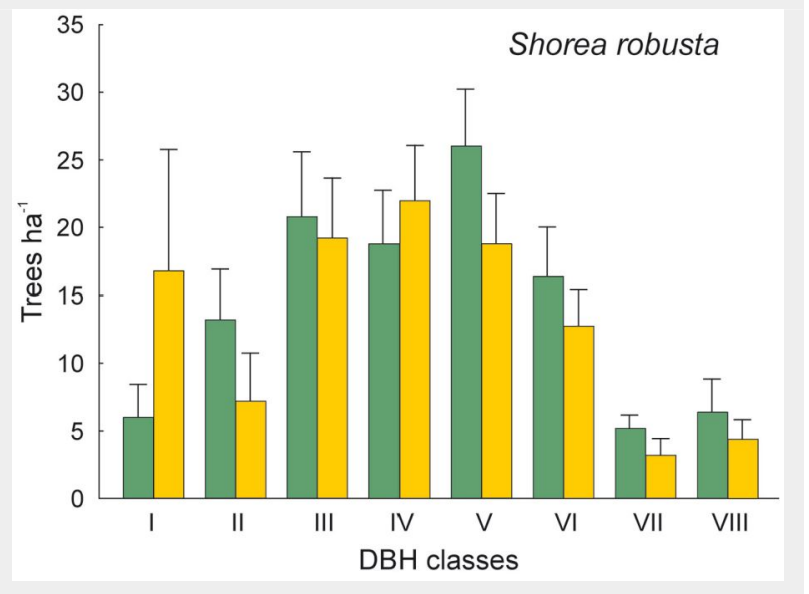

Fig. 4 - Distribution of Syzygium operculatum according its DBH classes in sal forest. Colors represent two sites: green - the park site (low human pressure, $\mathrm{N}$ $=25$ ) and yellow - the buffer site (higher human pressure, $\mathrm{N}=25$ ). Mean and SE are shown.

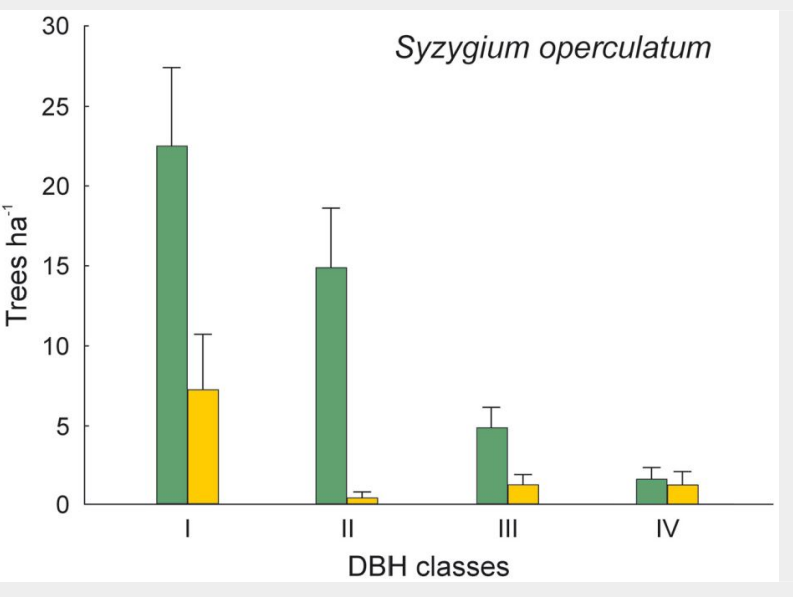

Fig. 5 - Distribution of Dillenia pentagyna according its DBH classes in sal forest. Colors represent the two study sites: green - the park site (low human pressure, $\mathrm{N}=25$ ) and yellow - the buffer site (higher human pressure, $\mathrm{N}=$ 25). Mean and SE are shown.

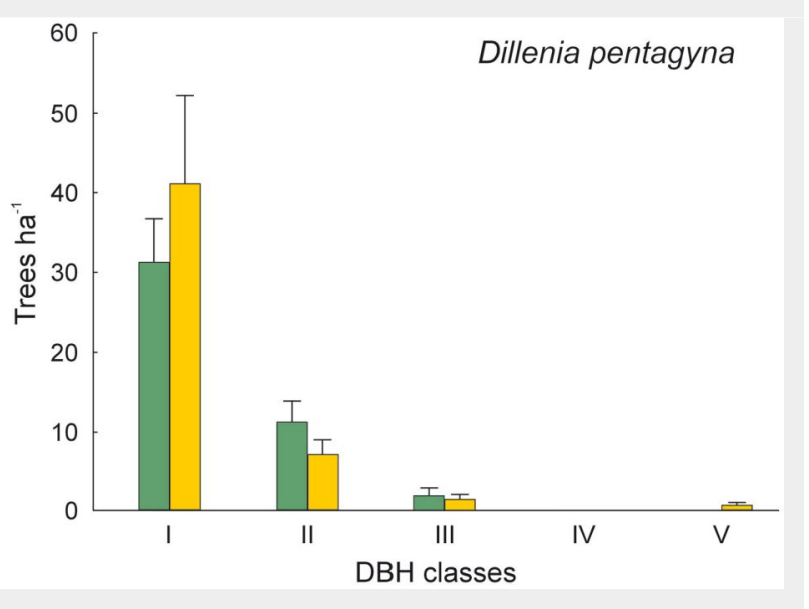

$\mathrm{N}=25$ ). The density of snags was twice as high in the park site compared to the buffer site, and this difference was significant (on average 10.0 and $5.2 \mathrm{ha}^{-1}$, respectively, Tab. 1). Overall, 18 tree species were identified, including 14 species at the park site and 13 at the buffer site (Tab. 2). Sal was the most common tree species in both sites ( $49.5 \%$ of trees in the park site, $\mathrm{N}=25$ and $45.7 \%$ in the buffer site, $\mathrm{N}=25$ ). In the park site, the next abundant species were D. pentagyna (19.5\%) and S. operculatum (19.1\%). Terminalia alata, which was not recorded on the park site, was the second most numerous species in the buffer site (22.6\%), followed by D. pentagyna (21.5\%). All other species were less common, representing $0.2-3.0 \%$ of trees at the park site and $0.2-4.4 \%$ at the buffer site (Tab. 1).

S. robusta was the most abundant dead tree in both study sites ( 11 trees in the park site and 8 trees in the buffer site), while $S$. operculatum was represented by 7 snags in the park site and 3 snags in the buffer site. One T. alata snag was found in the buffer site, and the remaining dead trees were not identified. Dead trees were $4.2 \%$ of all standing trees in the park site and $2.2 \%$ in the buffer site.

The DBH of all live trees in this study ranged from 10 to $111 \mathrm{~cm}$. Overall, trees belonging to DBH classes I and II corresponded to $54.0 \%$ in the park site $(\mathrm{N}=25)$ and $51.3 \%$ of all live trees in the buffer site $(\mathrm{N}=$ 25). Trees with $\mathrm{DBH} \geq 50 \mathrm{~cm}$ were $23.9 \%$ of the total trees in the park site and $22.4 \%$ in the buffer site (Fig. 2). S. robusta was the most represented species in classes III-VI in the park site, and in classes I and III-VI in the buffer site (Fig. 3). S. operculatum was recorded only in classes I-IV at both sites, though it was much more abundant in the park site than in the buffer site (Fig. 4). Similarly, D. pentagyna was found mostly in DBH class I and II at both sites (Fig. 5). Dead trees were found in classes I-VI. The thinnest snags (I class) dominated at the park site, while DBH classes III-IV dominated at the buffer site (Fig. 6).

\section{Cavity trees}

Density of trees with at least one cavity was slightly higher in the park site (on average: $16.0 \mathrm{ha}^{-1}, \mathrm{~N}=25$ ) compared to the buffer site (12.4 ha-1, N = 25), but such difference was not significant ( $p>0.05$ - Tab. 1). Cavities were found only in $6.7 \%$ of all trees in the park site and in $5.3 \%$ trees in the buffer site. Most cavity trees were alive $(82.5 \%$ in the park site and $90.3 \%$ in the buffer site Tab. 3), with no significant differences between sites $\left(X^{2}=0.36, d f=1, p=0.5513\right.$ with Yates correction). Live cavity trees were $5.8 \%$ in the park site and $4.9 \%$ of all live trees in the buffer site, while dead cavity trees represented 28.0 and $23.1 \%$ of all snags, respectively. Snags were overrepresented among the cavity trees both at the park site $\left(X^{2}=13.85, \mathrm{df}=1, \mathrm{p}=0.0002\right)$ and at the buffer site $\left(\chi^{2}=6.45, d f=1, p=\right.$ o.0111). 
Considering all 50 plots from both sites together, only one cavity was found in 50 out of 71 cavity trees, while 21 trees had from 2 to 5 cavities. In 16 trees two cavities were found, and only five trees had more than two cavities. In live cavity trees an average of $1.41 \pm 0.88$ cavities $(n=61)$ were found, and in snags $1.80 \pm 1.23$ cavities $(n=10)$, but this difference was not significant $(z=1.17, p=0.2406)$.

We recorded cavities in eight tree species. In both sites most cavities were found on trees of three species, i.e., S. robusta, S. operculatum and D. pentagyna. The other species rarely contained cavities (Tab. 3 ). Some species were clearly overrepresented among cavity trees: Syzygium operculatum in all plots (Ivlev's index 0.37 in the park site and 0.44 in the buffer site), Myrsine semiserrata and Semecarpus anacardium in the buffer site (Ivlev's index 0.65 and 0.72 , respectively - Fig. 7).

Cavity trees were on average thinner in the park site (DBH $38.7 \pm 19.97 \mathrm{~cm}, \mathrm{n}=40$ ) compared to the buffer site $(47.7 \pm 22.53$ $\mathrm{cm}, \mathrm{n}=31$ ), but these differences were not significant $(z=-1.95, p=0.0508)$. DBH of cavity trees ranged from 12 to $111 \mathrm{~cm}$, and differed depending on the species: the thickest were $S$. robusta $(55.7 \pm 22.48 \mathrm{~cm}, \mathrm{n}$ = 33), while $S$. operculatum had $29.7 \pm 10.34$ $\mathrm{cm}, \mathrm{n}=19$ and $\mathrm{D}$. pentagyna $26.87 \pm 7.51$ $\mathrm{cm}, \mathrm{n}=10$ (Fig. 8). Two-thirds of cavity trees were at least $30 \mathrm{~cm}$ in DBH. Within DBH classes, thickest trees were overrepresented: in the park site VIII class $\left(E_{i}=0.47\right)$, in the buffer site VIII and VII $\left(E_{i}=0.63\right.$ and 0.52, respectively - Fig. 9).

The generalized linear models indicated that tree species, tree condition and DBH were important variables for predicting the presence of cavities (Tab. 4). DBH had a significant positive effect - the larger the DBH of a tree, the higher the probability of cavity presence $(z=5.20, p<0.001)$. Presence of cavities was less likely in dead trees, as suggested by the significant effect of tree condition. The results indicated that chances for the presence of cavities significantly differed between the tree species (Tab. 4).

\section{Cavities}

The density of cavities was on average $22.4 \pm 4.04 \mathrm{ha}^{-1}$ in the park site $(\mathrm{N}=25)$ and $19.2 \pm 3.31 \mathrm{ha}^{-1}$ in the buffer site $(\mathrm{N}=25)$, and these differences were not significant ( $p>0.05$ - Tab. 1). Most of the cavities were non-excavated (natural cavities, $71.4 \%$ in the park site and $77.1 \%$ in the buffer site Tab. 1), and the proportion of natural and excavated cavities in the two sites was similar $\left(X^{2}=0.43, \mathrm{df}=1, \mathrm{p}=0.5120\right)$. Only three out of the 27 woodpecker-made cavities were located in snags (11.1\%) while almost one-fifth of 77 natural cavities (19.5\%) were located in snags.

\section{Discussion}

Despite the different management regimes, we found that the two study sites

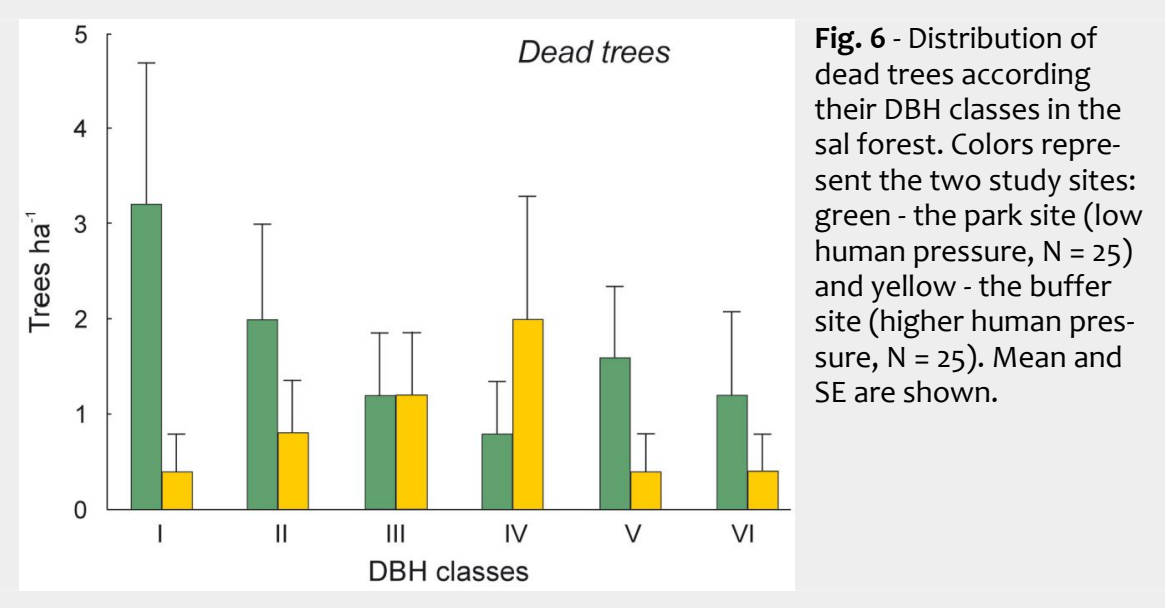

Tab. 3 - Number of cavity bearing trees and number of cavities according to tree species in the park site (totally $2.5 \mathrm{ha}$ ) and in the buffer site (2.5 ha).

\begin{tabular}{|c|c|c|c|c|c|c|c|c|c|}
\hline \multirow{3}{*}{ Species } & \multicolumn{3}{|c|}{ Park site } & \multicolumn{3}{|c|}{ Buffer site } & \multicolumn{3}{|l|}{ Total } \\
\hline & \multicolumn{2}{|c|}{ Cavity trees } & \multirow{2}{*}{$\begin{array}{c}\text { No. of } \\
\text { Cavities }\end{array}$} & \multicolumn{2}{|c|}{ Cavity trees } & \multirow{2}{*}{$\begin{array}{l}\text { No. of } \\
\text { Cavities }\end{array}$} & \multicolumn{2}{|c|}{ Cavity trees } & \multirow{2}{*}{$\begin{array}{l}\text { No. of } \\
\text { Cavities }\end{array}$} \\
\hline & Live & Dead & & Live & Dead & & Live & $\overline{\text { Dead }}$ & \\
\hline Shorea robusta & 14 & 2 & 20 & 15 & 2 & 21 & 29 & 4 & 41 \\
\hline $\begin{array}{l}\text { Syzygium } \\
\text { operculatum }\end{array}$ & 13 & 2 & 20 & 3 & 1 & 6 & 16 & 3 & 26 \\
\hline Dillenia pentagyna & 4 & 0 & 5 & 6 & 0 & 13 & 10 & 0 & 18 \\
\hline $\begin{array}{l}\text { Myrsine } \\
\text { semiserrata }\end{array}$ & 0 & 0 & 0 & 1 & 0 & 5 & 1 & 0 & 5 \\
\hline Terminalia alata & 0 & 0 & 0 & 2 & 0 & 2 & 2 & 0 & 2 \\
\hline $\begin{array}{l}\text { Semecarpus } \\
\text { anacardium }\end{array}$ & 0 & 0 & 0 & 1 & 0 & 1 & 1 & 0 & 1 \\
\hline Syzygium cumini & 1 & 0 & 1 & 0 & 0 & 0 & 1 & 0 & 1 \\
\hline Toona ciliata & 1 & 0 & 1 & 0 & 0 & 0 & 1 & 0 & 1 \\
\hline Unknown species & 0 & 3 & 9 & 0 & 0 & 0 & 0 & 3 & 9 \\
\hline Total & 33 & 7 & 57 & 28 & 3 & 48 & 61 & 10 & 104 \\
\hline
\end{tabular}

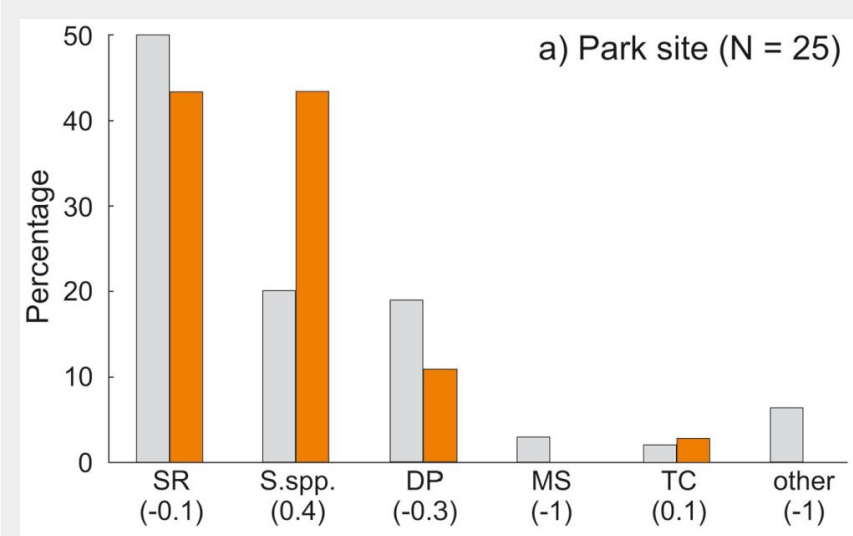

Fig. 7 - Percentage of cavity trees in relation to tree species availability in: (a) the park site (low human pressure); and (b) the buffer site (higher human pressure). All live and dead trees combined. (SR): Shorea robusta; (S.spp): Syzygium spp.; (DP): Dillenia pentagyna;

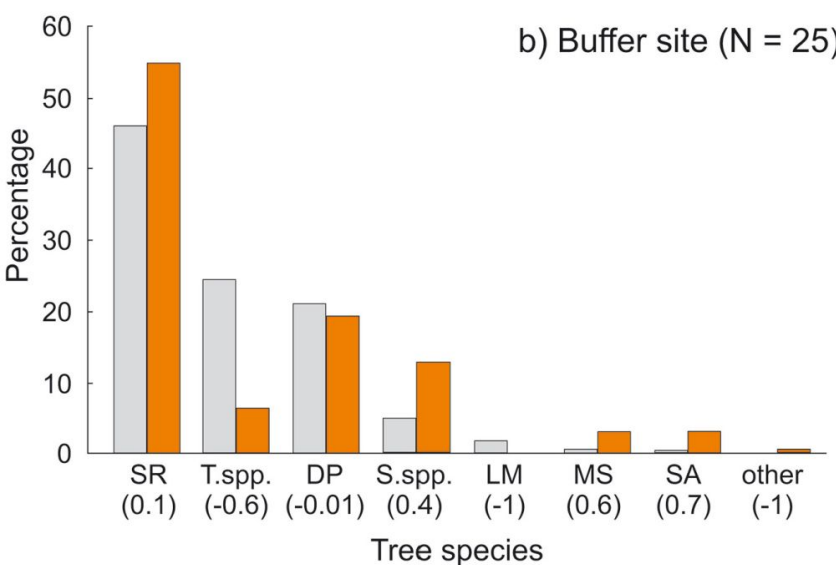
(MS): Myrsine semiserrata; (TC): Toona ciliata; (T.spp.): Terminalia spp.; (LM): Litsea monopetala; (SA): Semecarpus anacardium. Ivlev's electivity index in parentheses (positive values: overrepresented species; negative values: underrepresented species). Colors represent trees: grey resources; orange cavity trees. 
Fig. 8 - Average DBH of the most common tree species with cavities (live and dead combined) in all study plots in the sal forest. Boxes represent the mean $\pm S D$, whiskers represent \pm SE.

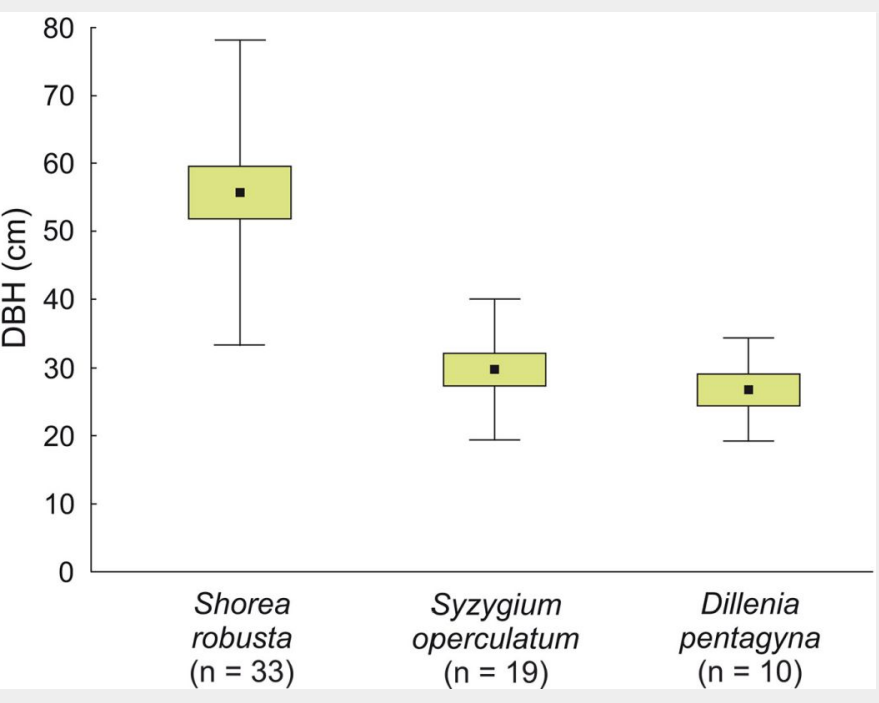

Fig. 9 - Percentage of cavity trees in relation to DBH classes availability in: (a) the park site (low human pressure); and

(b) the buffer site (higher human pressure). All live and dead trees com-

bined. Ivlev's electivity index in parentheses (positive values: overrepresented DBH classes; negative values: underrepresented DBH classes). Colors represent trees: grey-resources, orange - cavity trees.
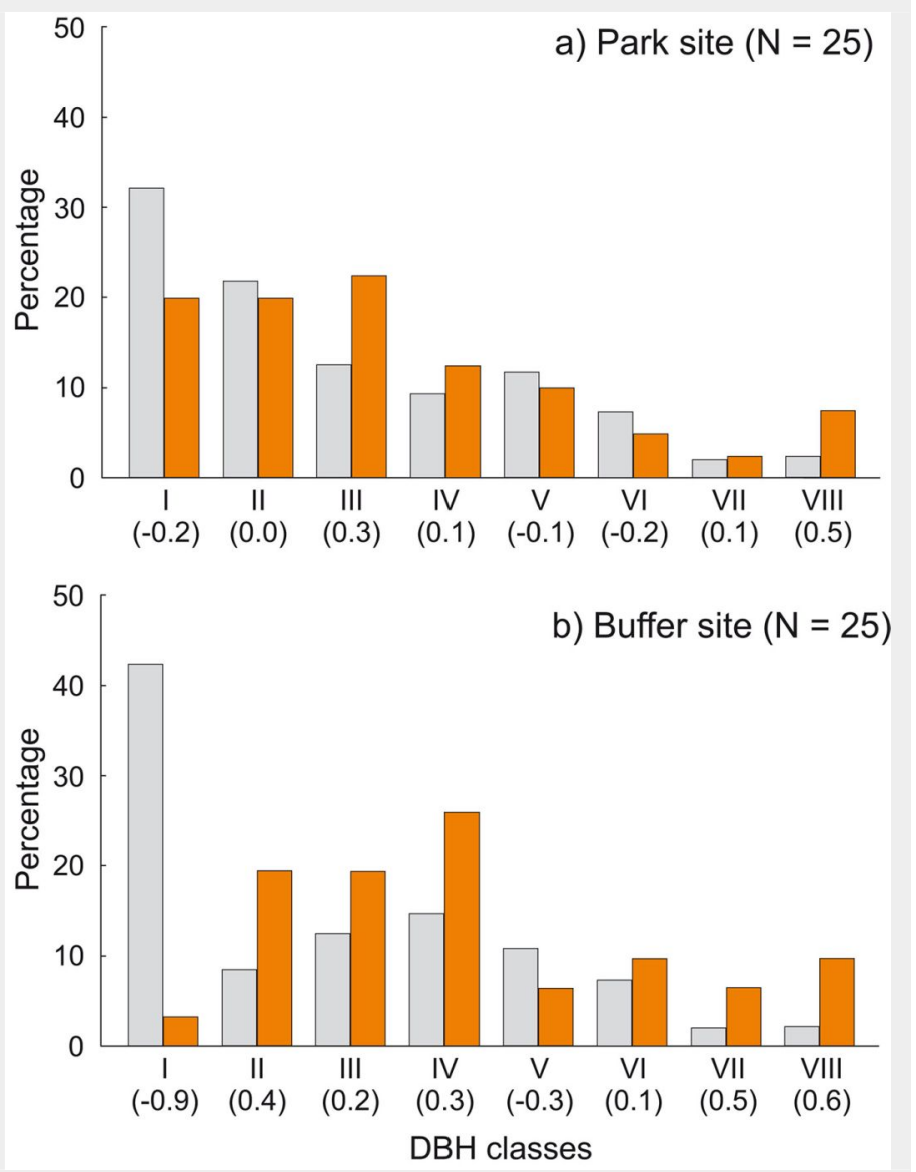

Tab. 4 - Generalized linear models (GLMs) predicting the probability of a cavity occurrence in trees $(\mathrm{N}=1049$, cavity present $=68$, cavity absent $=981)$. The top-ranked model (first line), selected by step-wise deletion using the Akaike's information criterion (AIC), was used to estimate the parameters reported in Tab. 5. (w): Akaike weights; (AUC): area under the curve.

\begin{tabular}{|c|c|c|c|c|}
\hline Model & AIC & $\triangle \mathrm{AIC}$ & $w$ & AUC \\
\hline Species + Condition + DBH & 474.52 & 0 & 0.02 & 0.743 \\
\hline Species + Condition + DBH + Site & 474.99 & 0.47 & 0.08 & 0.749 \\
\hline Species + Condition + DBH + Site + Condition $\times$ DBH & 475.71 & 1.19 & 0.21 & 0.750 \\
\hline $\begin{array}{l}\text { Species + Condition }+ \text { DBH }+ \text { Site + Condition } \times \text { DBH } \\
+ \text { Site } \times \text { DBH }\end{array}$ & 477.71 & 3.19 & 0.31 & 0.752 \\
\hline $\begin{array}{l}\text { Species + Condition }+ \text { DBH }+ \text { Site }+ \text { Condition } \times \text { DBH } \\
+ \text { Site } \times \mathrm{DBH}+\text { Species } \times \mathrm{DBH}\end{array}$ & 480.88 & 6.36 & 0.39 & 0.786 \\
\hline
\end{tabular}

(the park site and the buffer site) were structurally similar. This may be explained by the fact that both sites are included in a conservation area, with only some differences in the human impact (see below). Indeed, the two study sites represent an intermediate part of a gradient from natural to heavily-managed sal forests, whose extremes are likely to present more pronounced differences. Nonetheless, our study sites differed in several structural parameters like density of snags, density of several tree species and the distribution of size classes of trees. Moreover, we found a positive effect of tree size and condition on the presence of cavities, i.e., cavities were significantly more frequent on living trees with larger DBH. Our main results and their implications for the conservation of biodiversity in sal forests are discussed below in a management perspective.

\section{Trees in studied areas}

The lower density of snags observed at the buffer site may be easily explained by a more intense removal of dead wood by villagers. The Chitwan National Park authorities does not allow removal of dead trees within the park, though some snags are illegally removed regardless (Straede \& Helles 2000). Annual prescribed fires also has the potential to lower the number of snags in both sites, as dead trunks of some tree species burn more readily than other species that are fire resistant (e.g., sal dead trunks - Gautam \& Devoe 2005). In general, the amount of dead wood is usually much lower in managed forests in comparison to protected forests (Walankiewicz et al. 2002, Kennedy et al. 2010, Czeszczewik et al. 2013). However, this pattern is highly dependent on forest history, intensity of forest management, natural disturbance regimes and forest type (Lõhmus et al. 2005, Czeszczewik et al. 2015).

As compared to temperate forests, snags are generally less abundant in the tropical forest due to their higher decomposition rates (Gibbs et al. 1993). Indeed, in the European temperate deciduous forests of the Białowieża National Park (Poland), the proportion of dead trees with $\mathrm{DBH}>20 \mathrm{~cm}$ was $9.9 \%$ of the total number of stems, while their density was as much as 26.7 trees ha-1 (Walankiewicz et al. 2002). Such figure is about 4-6 times higher than that observed at the Chitwan National Park, which has a subtropical monsoon climate with high humidity during the rainy season, thus favoring a more rapid decomposition of wood. However, S. robusta, the dominant species in our study area (both in terms of living and dead trees) is extremely durable and resistant to decay (Orwa et al. 2009).

The thinnest DBH classes (I and II) of living trees represented half of all trees found in each studied site, indicating a well established regeneration at both sites. The most common species S. robusta had more trees of the thinnest class in the buffer site 
stand than in the park site. This may be due to the frequent logging and firewood collection at the buffer site as compared with the park site, thereby creating suitable conditions for younger generation of trees to develop. Similarly, the DBH class of S. operculatum ranged from I to IV class in both forest types with higher presence in the park site, while $D$. pentagyna ranged from I to III DBH classes with a higher share in the buffer site.

An interesting finding is the reverse pattern of occurrence of S. operculatum and T. alata in the park site vs. the buffer site. Both Syzygium operculatum and Terminalia alata represent the seral communities towards the climax of the sal forest. Such species are found more often in the mixed forest type, i.e., in the buffer site than in the relatively pure sal stand of the park site. However, S. operculatum and T. alata trees are also found in the park site but only at the edge forest/grassland. S. operculatum has no economic or cultural value, though its edible fruits likely favor seed dispersal by people. Also, both species are not particularly palatable for cattle, thus having a higher chance of persistence in the forest. On the other hand, T. alata has valuable timber, and sometimes the leaves are used as fodder for cattle. As a consequence, branch cutting may promote the formation of cavities in this species.

\section{Characteristic of cavity trees}

The average density of cavities in our study was higher than the global average estimated by Remm \& Lõhmus (2011) which was 16 ha $^{-1}$. However, cavity density may be much higher in low-latitude forests (Pattanavibool \& Edge 1996, Vázquez \& Renton 2015). It was well documented in North American forests that, when nonexcavated cavities are scarce, tree stands can sustain anyway healthy community of cavity nesters if enough suitable trees for excavators are available (Aitken \& Martin 2004). A meta-analysis by Remm \& Lõhmus (2011) showed that forest management strongly affects the distribution of tree cavities. A surplus of tree cavities can exist in natural forests (Edington \& Edington 1972, Walankiewicz 1991, Carlson et al. 1998, Cornelius et al. 2008, Wesołowski 2011). In this study, we found a similar availability of cavities at two sites that nominally differed in their management intensity. Nonetheless, the human impact on the park site was not negligible (as mentioned above), and this could have hampered the detection of differences between sites under different management intensities. However, it is worth to notice that, despite the human use of the forest for firewood and livestock, quite a few cavities were found at the buffer site. This is in contrast with the outcome of intensive forest management practices applied in European or American forests, that dramatically reduce tree cavity resources (Cockle et al. 2010, Walankiewicz et al. 2014).

Tab. 5 - Parameter estimates for the minimal adequate model $(\mathrm{AIC}=474.52)$ for the prediction of the probability of cavity occurrence in trees $(\mathrm{N}=1049$, cavity present $=$ 68 , cavity absent $=981$ ). The incidence of cavities in trees was the response variable (binomial GLM). Dillenia pentagyna was the reference species to which other species were compared.

\begin{tabular}{lcccc}
\hline Coefficients & Estimate & Std. Error & $\mathbf{z}$ value & $\operatorname{Pr}(>|\mathbf{z}|)$ \\
\hline Intercept & -2.307 & 0.612 & -3.768 & $<0.001$ \\
Other species & -0.685 & 1.086 & -0.631 & 0.528 \\
Species Litsea monopetala & -14.820 & 1088.0 & -0.014 & 0.989 \\
Species Myrsine semiserrata & -0.244 & 1.090 & -0.224 & 0.823 \\
Species Semecarpus anacardium & 0.008 & 1.105 & 0.007 & 0.994 \\
Species Shorea robusta & -1.464 & 0.502 & -2.915 & 0.004 \\
Species Syzygium operculatum & 0.670 & 0.427 & 1.570 & 0.116 \\
Species Terminalia alata & -2.296 & 0.850 & -2.701 & 0.007 \\
Species Toona ciliata & 0.313 & 1.096 & 0.286 & 0.775 \\
Species Trewia nudiflora & -14.750 & 1314.0 & -0.011 & 0.991 \\
Tree condition Live & -1.376 & 0.499 & -2.756 & 0.006 \\
DBH & 0.044 & 0.009 & 5.217 & $<0.001$ \\
\hline
\end{tabular}

Although most cavities were found in S. robusta (the most common species in the study sites), cavities were clearly underrepresented in this species. Differences in cavity occurrence among species have been already reported (Aitken \& Martin 2004, Wesołowski 2011, 2012). In our study, in addition to $S$. robusta, S. operculatum and D. pentagyna were important cavity trees. On the other hand, our results concerning $S$. operculatum are contradictory to some extent (compare Tab. 5 and Fig. 7), suggesting that not the species itself but its DBH distribution may affect the presence of cavities in this species. When DBH was included in the model as covariate, the species effect of $S$. operculatum was not significant anymore. Furthermore, both $S$. operculatum and D. pentagyna, that actually never grow very high and thick, captured a substantial proportion of cavities in our study. Although the wood of the abovementioned species is considered hard ( $D$. pentagyna), very hard (S. operculatum) or even extremely hard (S. robusta), their predisposition to the formation of cavities is apparent (Khanna \& Chaturvedi 2012). This is probably linked to processes like wood cracking, branch breakage and also wood decaying caused by fungi. For example, old specimens of $\mathrm{S}$. robusta are generally resistant to fire, but fire wounds result in infection and the trees became prone to heart rot due to fungi (Bakshi 1957).

Cavity trees were found mostly to be relatively thick (average DBH: $43 \mathrm{~cm}$ ). Most cavities were found on living trees rather than on snags in both forest types. Similar result were found in a tropical forest of Costa Rica (Boyle et al. 2008) and in Canadian forests (Aitken \& Martin 2007, Boyle et al. 2008). In contrast, Hussain et al. (2013) found $59 \%$ of cavities in dead trees in a coniferous forest of Pakistan, and Walankiewicz et al. (2011) recorded the threefourth of cavities in snags of coniferous forests in the Białowieża National Park (Poland). In summary, the proportion of cavities found in living trees vs. snags seems to be dependent on stand type, as well as on the wood characteristics of the tree species (softness/hardness).

Our study revealed that non-excavated cavities in both forest types (77\%) were more common than excavated (woodpecker-made) cavities. In a mature forest in Mongolia three-fourth of secondary cavity birds nested in non-excavated cavities (Bai et al. 2003). The presence of woodpeckers does not seem a prerequisite to support a diverse cavity-dependent community, as exemplified by the existence of forest ecosystems without woodpeckers or other active excavators in Australia and New Zealand (Gibbons \& Lindenmayer 2002). In contrast, the Chitwan forest has a diverse woodpecker community (over 15 species) providing a fairly high number of newlyexcavated cavities each year. Our study from sal forest indicates that these cavities account only for a minor share of all available cavities. The assessment of their use by cavity-dependent organisms shall be the object of future research.

\section{Management implications}

Although we did not find any evidence that human impact may reduce the density of tree cavities, a lower density of snags at the buffer site compared to the park site was found. Dead trees are relatively important for the occurrence of tree cavities. Furthermore, based on our results we cannot exclude that several differences could exist in the usage by dependent organisms of snag cavities as compared with those found on living trees. According to the operational plan of forest management in the Khorsor buffer zone, selected dead, dying, diseased, depressed wood is allowed to be removed from the forest. Based on the above considerations, we recommend to ensure the presence of some snags in the managed forests, as they are the potential substrate for cavities of specialized species, as well as the habitat for beetles and other insects which represent the preferential food for woodpeckers. Moreover, we found that non-excavated cavities on living trees were more abun- 
dant than woodpecker-made cavities at both study sites. Based on our findings, $S$. robusta and $S$. operculatum are particularly important tree species for cavity formation in both living and dead trunks. Therefore, management plans should take into account the release of a certain amount of potential cavity substrate, both living trees and snags, according to the species and their trunk dimensions.

Our study is based on a limited dataset not covering the whole spectrum of environmental conditions of the sal forests in Nepal. Indeed, the two study sites represent a small part of the broader gradient from natural to heavily-managed sal forests. Therefore, our results should be considered as an initial assessment of cavity resources in this broadly-distributed forest ecosystem. Further studies are needed to throw light on the use of cavity resources by the community of cavity-dependent organisms, as well as on S. robusta as keystone tree species for cavity formation in the forests of the whole Indian Subcontinent.

\section{Acknowledgements}

This research was funded by the Swedish University of Agricultural Sciences, Sweden, and Siedlce University of Natural Sciences and Humanities, Poland (19/91/S). Anil Gurung, Suresh Chaudhari, Shiva Raj Thanet, Prakash Chapaghai and Bindu Adhikari helped us in the field work. The Institute of Forestry, Pokhara Campus, Department of National Park and Wildlife Conservation, and the Chitwan National Park and National Trust for Nature Conservation authority made our work possible by providing permission to conduct fieldwork. We thank all of the contributors. We also heartily thank Kerry L. Nicholson for valuable comments on an earlier version of manuscript and for language improvement.

\section{References}

Aitken KEH, Martin K (2004). Nest cavity availability and selection in aspen-conifer groves in a grassland landscape. Canadian Journal of Forest Research 34: 2099-2109. - doi: 10.1139/x04086

Aitken KEH, Martin K (2007). The importance of excavators in hole nesting communities: availability and use of natural tree holes in old mixed forests of western Canada. Journal of Ornithology 148: 425-434. - doi: 10.1007/s10336-0070166-9

Angelstam P, Mikusiński G (1994). Woodpecker assemblages in natural and managed boreal and hemiboreal forest - a review. Annales Zoologici Fennici 31: 157-172. [online] URL: http:// www.jstor.org/stable/23735508

Bai M-L, Wichmann F, Mühlenberg M (2003). The abundance of tree holes and their utilization by hole-nesting birds in a primeval boreal forest of Mongolia. Acta Ornithologica 38: 95-102. - doi: 10.3161/068.038.0205

Bakshi BK (1957). Heart rot in relation to management of Sal. Indian Forester 83: 651-661.
Boyle WA, Ganong CN, Clark DB, Hast MA (2008). Density, distribution and attributes of tree cavities in an old-growth tropical rain forest. Biotropical 40: 241-245. - doi: 10.1111/j.17447429.2007.00357.x

Bull EL, Peterson SR, Thomas JW (1986). Resource partitioning among woodpeckers in northeastern Oregon. Pacific Northwest Research Station, USDA Forest Service, Portland, OR, USA, pp. 19. [online] URL: http://books.goo gle.com/books?id=ni1OYC8khqQC

Burnham KP, Anderson R (2002). Model selection and multi-model inference: a practical information-theoretic approach ( $2^{\text {nd }}$ edn). Springer-Verlag, New York, USA, pp. 83.

Carlson A, Sandström U, Olsson K (1998). Availability and use of natural tree holes by cavity nesting birds in a Swedish deciduous forest. Ardea 86: 109-119. [online] URL: http://www.divaportal.org/smash/record.jsf?pid=diva2:137120\&d swid $=8958$

Cockle KL, Martin K, Drever MC (2010). Supply of tree-holes limits nest density of cavity-nesting birds in primary and logged subtropical Atlantic forest. Biological Conservation 143: 2851-2857. doi: 10.1016/j.biocon.2010.08.002

Cockle KL, Martin K, Wesołowski T (2011). Woodpeckers, decay, and the future of cavity-nesting vertebrate communities worldwide. Frontiers in Ecology and the Environment 9: 377-382. doi: $10.1890 / 110013$

Cooke HA, Hannon SJ (2011). Do aggregated harvests with structural retention conserve the cavity web of old upland forest in the boreal plains? Forest Ecology and Management 261: 662-674. - doi: 10.1016/j.foreco.2010.11.023

Cornelius C, Cockle K, Politi N, Berkunsky I, Sandoval L, Ojeda V, Rivera L, Hunter Jr M, Martin $\mathrm{K}$ (2008). Cavity-nesting birds in neotropical forests: cavities as a potentially limiting resource. Ornitologia Neotropical 19: 253-268.

Czeszczewik D, Walankiewicz W (2003). Natural nest sites of the Pied Flycatcher in a primeval forest. Ardea 91: 221-230. [online] URL: http:// www.researchgate.net/profile/Wieslaw_Walan kiewicz/publication/228603801

Czeszczewik D, Walankiewicz W, Mitrus C, Tumiel T, Stanski T, Sahel M, Bednarczyk G (2013). Importance of dead wood resources for woodpeckers in coniferous stands of the Białowieża Forest. Bird Conservation International 23: 414425. - doi: 10.1017/S0959270912000354

Czeszczewik D, Zub K, Stanski T, Sahel M, Kapusta A, Walankiewicz W (2015). Effects of forest management on bird assemblages in the Białowieża Forest, Poland. iForest 8 (3): 377385. - doi: 10.3832/ifor1212-007

DNPWC (2011). Annual report. Government of Nepal, Ministry of Forest and Soil Conservation, Department of National Park and Wildlife Conservation, Kathmandu, Nepal, pp. 100.

Edington JM, Edington MA (1972). Spatial patterns and habitat partition in the breeding birds of an uplandwood. Journal of Animal Ecology 41:331-357. - doi: $10.2307 / 3472$

Gautam KH, Devoe NN (2005). Ecological and anthropogenic niches of sal (Shorea robusta Gaertn. F.) forest and prospects for multipleproduct forest management - a review. Forestry 79: 81-101. - doi: 10.1093/forestry/cpi063

Gibbons P, Lindenmayer D (2002). Tree hollows and wildlife conservation in Australia. CSIRO Publishing, Melbourne, Australia, pp. 211. [online] URL: http://books.google.com/books?id=6 Q28RIIsW_IC

Gibbs JP, Hunter ML, Melvin SM (1993). Snag availability and communities of cavity-nesting birds in tropical versus temperate forests. Biotropica 25: 236-241. - doi: 10.2307/2389188 Hosmer DW, Jovanovic B, Lemeshow S (1989). Best subsets logistic regression. Biometrics 45: 1265-1270. - doi: 10.2307/2531779

Hussain I, Abbasi S, Mirza SN, Anwar M, Rais M, Mahamood T (2013). Tree cavities and associated vertebrate fauna in a coniferous forest of Dhirkot, Azad Jammu and Kashmir part of Pakistan. Turkish Journal of Zoology 37: 647-658. doi: 10.3906/zoo-1209-32

Jacobs J (1974). Quantitative measurement of food selection. A modification of the forage ratio and Ivlev's electivity index. Oecologia 14: 413-417. - doi: 10.1007/BFo0384581

Kennedy RSH, Pabst RJ, Olsen KA, Spies TA (2010). Potential future dead wood dynamics in a multi-ownership region: the coastal province of Oregon, USA. Forest Ecology and Management 259: 312-322. - doi: 10.1016/j.foreco.2009. 10.020

Khanna LS, Chaturvedi AN (2012). Handbook of Forestry ( $4^{\text {th }}$ edn). Khanna Bandhu 7, Tilak Road, Deheradun, India, pp. 206.

Kumar R, Shahabuddin G, Kumar A (2011). How good are managed forests at conserving native woodpecker communities? A study in sub-Himalayan dipterocarp forests of northwest India. Biological Conservation 144: 1876-1884. doi: 10.1016/j.biocon.2011.04.008

Lammertink M (2004). A multiple-site comparison of woodpecker communities in Bornean lowland and hill forests. Conservation Biology 18: 746-757. - doi: 10.1111/j.1523-1739.2004.00046 .x

Lõhmus A, Lõhmus P, Remm J, Vellak K (2005). Old-growth structural elements in a strict reserve and commercial forest landscape in Estonia. Forest Ecology and Management 216: 201215. - doi: 10.1016/j.foreco.2005.05.031

Mikusiński G (2006). Woodpeckers (Picidae) distribution, conservation and research in a global perspective. Annales Zoologici Fennici 43: 86-95.

Müller-Böcker U (1991). Knowledge and evaluation of the environment in traditional societies of Nepal. Mountain Research and Development 11: 101-114. - doi: 10.2307/3673570

Nepal SK, Weber KE (1995). The quandary of local people-park relations in Nepal's Royal Chitwan National Park. Environmental Management 19: 853-866. - doi: 10.1007/BF02471937

Newton I (1994). The role of nest-sites in limiting the number of hole-nesting birds: a review. Biological Conservation 70: 265-276. - doi: 10.1016/ 0006-3207(94)90172-4

Newton I (1998). Population limitation in birds. Academic Press, San Diego, CA, USA, pp. 597. [online] URL: http://books.google.com/books? id=gU-7snBvdd8C

Orwa C, Mutua A, Kindt R, Jamnadass R, Simons $A$ (2009). Agroforestree database: a tree reference and selection guide version 4.0. World Agroforestry Centre (ICRAF), Nairobi, Kenya. [online] URL: http://www.worldagroforestry. 
org/resources/databases/agroforestree

Pattanavibool A, Edge WD (1996). Single-tree selection silviculture affects cavity resources in mixed deciduous forests in Thailand. Journal of Wildlife Management 60: 67-73. - doi: 10.2307/ 3802041

Poulsen BO (2002). Avian richness and abundance in temperate Danish forests: tree variables important to birds and their conservation. Biodiversity and Conservation 11: 1551-1566. doi: $10.1023 / A: 1016839518172$

R Development Core Team (2013). R: a language and environment for statistical computing. $R$ Foundation for Statistical Computing, Vienna, Austria. [online] URL: http://www.r-project.org Remm J, Lõhmus A (2011). Tree cavities in forest - The broad distribution pattern of keystone structure for biodiversity. Forest Ecology and Management 262: 579-585. - doi: 10.1016/j.for eco.2011.04.028

StatSoft I (2011). STATISTICA - data analysis software system, version 10 . Web site. [online] URL: http://www.statsoft.com

Straede S, Helles F (2000). Park-people conflict resolution in Royal Chitwan National Park, Nepal: buying time at high cost? Environmental Conservation 27: 368-381. - doi: 10.1017/S037689 2900000424

Straede S, Treue T (2006). Beyond buffer zone protection: a comparative study of park and buffer zone products' importance to villagers living inside Royal Chitwan National Park and to villagers living in its buffer zone. Journal of Environmental Management 78: 251-267. - doi: 10.1016/j.jenvman.2005.03.017

Tidemann CR, Flavel SC (1987). Factors affecting choice of diurnal roost site by tree-hole bats (Microchiroptera) in south-eastern Australia. Australian Wildlife Research 14: 459-473. - doi: 10.1071/WR9870459

Von Haartman L (1957). Adaptation in hole-nesting birds. Evolution 11: 339-347. - doi: 10.2307/24 05797

Vázquez L, Renton K (2015). High density of treecavities and snags in tropical dry forest of western Mexico raises questions for a latitudinal gradient. PLoS One 10: e0116745. - doi: 10.1371/ journal.pone.0116745

Walankiewicz W (1991). Do secondary cavity-nesting birds suffer more from competition for cavities or from predation in a primeval deciduous forest? Natural Areas Journal 11: 203-212.

Walankiewicz W, Czeszczewik D, Mitrus C (2007). Natural nest sites of the Collared Flycatcher Ficedula albicollis in lime-hornbeam-oak stands of a primeval forest. Ornis Fennica 84: 155-162.

Walankiewicz W, Czeszczewik D, Mitrus C, Bida E (2002). Znaczenie martwych drzew w lasach lisciastych dla zespolu dzieciolów w Puszczy Białowieskiej [Snag importance for woodpeckers in deciduous stands of the Białowieża Forest]. Notatki Ornitologiczne 43: 61-71. [in Polish]

Walankiewicz W, Czeszczewik D, Stanski T, Sahel M, Ruczynski I (2014). Tree cavity resources in spruce-pine managed and protected stands of the Białowieża Forest, Poland. Natural Areas
Journal 34: 501-515. - doi: 10.3375/043.034.0404 Walankiewicz W, Czeszczewik D, Tumiel T, Stanski T (2011). Woodpeckers abundance in the Białowieża Forest - a comparison between deciduous, strictly protected and managed stands. Ornis Polonica 52: 161-168.

Waters JR, Noon BR, Verner J (1990). Lack of nest site limitation in a cavity-nesting bird community. Journal of Wildlife Management 54: 239-245. - doi: 10.2307/3809036

Wesołowski T (1996). Natural nest sites of Marsh Tits Parus palustris in a primaeval forest (Białowieża National Park, Poland). Die Vogelwarte 38: 235-249.

Wesołowski T (2005). Virtual conservation: how the European Union is turning a blind eye to its vanishing primeval forests. Conservation Biology 19: 1349-1358. - doi: 10.1111/j.1523-1739.2005.0 0265.x

Wesołowski T (2011). "Lifespan” of woodpeckermade holes in a primeval temperate forest: a thirty-year study. Forest Ecology and Management 262: 1846-1852. - doi: 10.1016/j.foreco.2011. 08.001

Wesołowski T (2012). "Lifespan” of non-excavated holes in a primeval temperate forest: a 30 year study. Biological Conservation 153: 118-126. - doi: 10.1016/j.biocon.2012.04.017

Yanovlak SP (2001). The macrofauna of waterfilled tree holes on Barro Colorado Island, Panama. Biotropica 33: 110-120. - doi: 10.1111/j.17447429.2001.tboo161.x 